\title{
Removal of inorganic compounds from acidic solutions by sorption
}

\author{
Marian Holub, Magdalena Balintova \\ Technical University of Kosice, Faculty of Civil Engineering, Institute of Environmental Engineering, Vysokoskolska 4,04200 Kosice, Slovak Republic
}

\begin{abstract}
Manufacturing processes, primarily mining activities, often result in the production of effluents containing high amounts of inorganic pollutants e.g. heavy metals or sulphates. This category includes also low value $\mathrm{pH}$ waters with high content of heavy metals, known as acid mine drainage (AMD). Low value of $\mathrm{pH}$ of these waters is a result of hydrogen cations release into aqueous environment during the process of pyrite oxidation. Together with heaps and ponds belongs to the negative effects of mining activities in the form of environmental burdens.

According to Directive 2000/60/EC of the European Parliament it is necessary to ensure adequate water quality and protection of all water sources. In Slovak Republic, as the country with long mining traditions, now exist a few localities with existing AMD generation conditions (either in form of direct outflow from mine or leachate from tailing ponds).

Finding of the new and cheap options for treatment of these waters can increase the quality of the environment in these localities and thus prevent adverse effects on fauna, flora or human beings. A cost effective methods also include sorption techniques. Their main positives are high efficiency, low cost and high degree of modifiability and regenerability of the used sorbents.

This paper is focused on the utilization of natural sorbent for heavy metals removal from model sulphuric acid solutions (pH approx. 4). The adsorption properties of non-modified peat has been studied in order to determine its applicability for copper and zinc removal in treatment process of acid mine drainage (AMD). For purpose of the determination of the removal efficiencies of metals the experiments were performed under batch conditions using single and dual-component solutions under acidic conditions. The objectives of this work were to evaluate the effects of different parameters such as initial ion concentration, $\mathrm{pH}$ change or amount of the used sorbent on the sorption efficiency as an input data for further research of acid mine drainage treatment.
\end{abstract}

Keywords: sorption; copper; zinc; peat; acidic solutions.

\begin{tabular}{|ll|}
\hline Nomenclature \\
$C_{0} \quad$ initial metal ion concentration $(\mathrm{mg} / \mathrm{L})$ \\
$C_{e}$ & equilibrium metal ion concentration $(\mathrm{mg} / \mathrm{L})$ \\
$q$ & adsorption capacity per unit mass of adsorbent $(\mathrm{mg} / \mathrm{g})$ \\
$V$ & volume of the aqueous phase $(\mathrm{L})$ \\
$m$ & mass of the adsorbent $(\mathrm{g})$ \\
\hline
\end{tabular}

\section{Introduction}

Heavy metal ions such as copper, zinc, chromium, cadmium or lead can often be found in industrial waste water, and their discharge to the environment gives alarm impact to their acute toxicity to aquatic and terrestrial life, including humans. For example excessive intake of copper (over $1.0 \mathrm{mg} . \mathrm{L}-1$ in drinking water) is accumulated in the livers of human and animals, which results in hemochromatosis and gastrointestinal catarrh diseases [1]. It is especially toxic to fish, which are often in the first contact with polluting media.

The potential sources of toxic metal ions are, essentially, the industrial waste streams of metal cleaning and plating baths, paperboard and wood preservative-employing mills, the fertilizer industry, mining activities, etc. [2], [3].

Current metals removal technologies are result of a need by industry to achieve acceptable effluent quality standards set by the local governments. These conventional and emerging treatment methods for metals removal include precipitation, secondary co-precipitation, evaporative recovery, ion exchange, membrane separation, reductive electrolysis, differential precipitation, etc. [4-6].

Corresponding author: Marian Holub. E-mail address: marian.holub@tuke.sk

http://dx.doi.org/10.3846/enviro.2014.078

(C) 2014 The Authors. Published by VGTU Press. This is an open-access article distributed under the terms of the Creative Commons Attribution License, which permits unrestricted use, distribution, and reproduction in any medium, provided the original author and source are credited. 
In industrial treatment technologies, precipitation has found wide application for metals removal. The fact that precipitation can only reduce the dissolved metal concentration to the solubility product level, create the motivation for change away from these metal control technologies. Another problem is treatment of wastewaters containing low concentrations of heavy metals, what makes in this case applications of common methods for removing of heavy metals either technically complicated or economically unfavorable. Precisely such problems are creating a space for new and innovative methods for treatment of heavy metals contaminated wastewater.

Adsorption or ion-exchange onto low-cost particulate materials such as peat now offers an attractive, inexpensive option for the removal of colloidal and dissolved metals [7].

Peat is a polar, highly porous material that has significant applications as an adsorbent for removal of different pollutants from aqueous solutions. The formation of peat is due to incomplete degradation of organic matter. There are several types of peat. Their quality depends on the conditions affecting the degree of decomposition and also the type of peat-forming plant community. Generally, organic matter has a high metal adsorption capacity and the cation exchange capacity (CEC) of soil is positively correlated with the content of soil organic matter [8]. The amount of adsorption sites on the peat surface is $\mathrm{pH}$ dependent due to dissociation of hydrogen ions from carboxylic and phenolic groups on the peat surface [9], [10]. The exact mechanism of metal ion binding to peat is not well understood. Various mechanisms including ion exchange, complexation and surface adsorption have been proposed by researchers [11].

The paper presents a study of the uptake efficiency of $\mathrm{Zn}^{2+}$ and $\mathrm{Cu}^{2+}$ from single and dual-component synthetic acidic solutions (pH approx. 4). As an adsorbent a treated and non-modified natural peat under batch conditions was chosen. The adsorption properties of peat has been studied in order to determine its applicability for copper and zinc removal in treatment process of acid mine drainage (AMD). The objectives of the experiments were to evaluate the effects of different parameters such as initial ion concentration, $\mathrm{pH}$ change or amount of the used sorbent on the sorption efficiency.

\section{Material and methods}

\subsection{Adsorbent}

As a sorption material commercial non-modified peat "PEATSORB" (provided by REO AMOS; Slovakia) was used. In experiments was used finer heterogeneous fraction which was prepared by sieving through a $2 \mathrm{~mm}$ sieve. After sieving, the separated fraction of peat was dried at $105^{\circ} \mathrm{C}$ for $24 \mathrm{~h}$ and then allowed to cool in the desiccators before using in experimental set-up.

\subsection{Adsorbates}

Synthetic solutions of $\mathrm{Cu}^{2+}$ and $\mathrm{Zn}^{2+}$ were prepared from analytical grade $\mathrm{CuSO}_{4} .5 \mathrm{H}_{2} \mathrm{O}$ and $\mathrm{ZnSO}_{4} .7 \mathrm{H}_{2} \mathrm{O}$ respectively. Working solutions were prepared by further dilution to the desired initial concentration of appropriate heavy metal. The initial $\mathrm{pH}$ of each solution was adjusted to the required value $(\mathrm{pH} \approx 4)$ using $0.001 \mathrm{M}$ sulphuric acid. It should be noted that sulphate anions are not forming precipitates or complexes with copper and zinc cations at the test conditions and are considered to be inert.

\subsection{Apparatus and instrumentation}

Concentrations of metal ions before and after the experiments were determined by colorimetric method using Colorimeter DR890 (HACH LANGE, Germany) with combination of appropriate reagent. $\mathrm{pH}$ values were determined by $\mathrm{pH}$ meter inoLab ph 730 (WTW, Germany) which was standardized using buffer solutions of different pH values (4.01, 7.00).

\subsection{Batch adsorption experiments}

For the purpose of peat removal efficiencies investigation, batch adsorption experiments were carried out. Peat was mixed with $100 \mathrm{~mL}$ of single-component solutions containing $50 \mathrm{mg} / \mathrm{L}$ and $110 \mathrm{mg} / \mathrm{L}$ of copper and zinc cations, respectively. Effect of sorbent amount on removal efficiencies was also investigated; therefore dose of peat was modulated as follows: $1.0,3.0$ and $5.0 \mathrm{~g}$ per $100 \mathrm{~mL}$ of solution. After 24 hours reaction time, peat was removed by filtration through a laboratory filter paper for qualitative analysis, residual concentration of appropriate metal ion was determined by colorimetric method and $\mathrm{pH}$ change was also measured.

Acid mine drainage normally contains mixture of metal cations (e.g. $\mathrm{Zn}^{2+}, \mathrm{Cu}^{2+}, \mathrm{Mn}^{2+}, \mathrm{Pb}^{2+}, \mathrm{Fe}^{3+}, \mathrm{Cr}^{3+}$ etc). Another test was performed to investigate the influence of the presence of another cation on the adsorption capacity of peat. Dual component solutions containing concentrations of $50 \mathrm{mg} / \mathrm{L}$ and $110 \mathrm{mg} / \mathrm{L}$ of both types of cations $\left(\mathrm{Cu}^{2+}\right.$ and $\left.\mathrm{Zn}^{2+}\right)$ were made and mixed with natural peat for 24 hours. Experiments were performed by adding of 1.0, 3.0 and $5.0 \mathrm{~g}$ of peat and mixed with $100 \mathrm{~mL}$ of solution containing upper listed concentrations of metals.

After 24 hours reaction time, the peat was removed by filtration through a laboratory filter paper for qualitative analysis, residual concentrations of metal ions were determined and $\mathrm{pH}$ change was also measured. 
All batch experiments were carried out at room temperature $\left(23 \pm 0.2^{\circ} \mathrm{C}\right)$ in beakers under static conditions. Average of two replications was reported for each adsorption process.

The copper and zinc adsorption capacities were calculated by the following equation:

$$
q=\frac{\left(C_{0}-C_{e}\right)}{m} \times V
$$

The percentage adsorption (\%) was calculated using the following equation:

$$
\% \text { Adsorption }=\frac{\left(C_{0}-C_{e}\right)}{C_{0}} \times 100 \%
$$

\section{Results}

\subsection{Single-component solutions efficiencies}

The effects of the adsorbent dose on the uptake of heavy metal ions are shown in Table 1 and 2 . It was observed that increase of dosage resulted to increasing of the amount of the heavy metals uptake, because of increasing of adsorption sites amount. From the result is also obvious, that copper cations are better adsorbed than zinc.

When the initial concentrations of $\mathrm{Cu}$ (II) solution are changed from $50 \mathrm{mg} / \mathrm{L}$ to $110 \mathrm{mg} / \mathrm{L}$ (comparison between Table 1 and 2) the absolute amount of $\mathrm{Cu}$ (II) ions adsorbed per unit of the peat increases from $3.44 \mathrm{mg} / \mathrm{g}$ (70.02\% removal) to $5.92 \mathrm{mg} / \mathrm{g}\left(54.61 \%\right.$ removal) at $21{ }^{\circ} \mathrm{C}, \mathrm{pH} 4$ and adsorbent dose $1 \mathrm{~g} / 100 \mathrm{~mL}$. However, the percent of adsorption decreases with increasing concentration of $\mathrm{Cu}$ (II). The same trend applies also to zinc adsorption.

Table 1. The removal efficiencies of copper and zinc after $24 \mathrm{~h}$ of contact with $100 \mathrm{~mL}$ single-component solutions; initial concentration $50 \mathrm{mg} / \mathrm{L}$, initial $\mathrm{pH} \approx 4$

\begin{tabular}{cccc}
\hline & \multicolumn{4}{c}{ Removal efficiencies [\%] at different adsorbent dose } \\
\hline & $1.0 \mathrm{~g}$ & $3.0 \mathrm{~g}$ & $5.0 \mathrm{~g}$ \\
\hline $\mathrm{Cu}^{2+}$ & 70.02 & 80.35 & 84.58 \\
\hline $\mathrm{Zn}^{2+}$ & 60.06 & 74.43 & 81.02 \\
\hline
\end{tabular}

Table 2. The removal efficiencies of copper and zinc after $24 \mathrm{~h}$ of contact with $100 \mathrm{~mL}$ single-component solutions; initial concentration $110 \mathrm{mg} / \mathrm{L}$, initial $\mathrm{pH} \approx 4$

\begin{tabular}{cccc}
\hline & \multicolumn{3}{c}{ Removal efficiencies [\%] at different adsorbent dose } \\
\hline & $1.0 \mathrm{~g}$ & $3.0 \mathrm{~g}$ & $5.0 \mathrm{~g}$ \\
\hline $\mathrm{Cu}^{2+}$ & 54.61 & 76.89 & 81.79 \\
\hline $\mathrm{Zn}^{2+}$ & 46.17 & 59.11 & 75 \\
\hline
\end{tabular}

\section{2. $p H$ change}

$\mathrm{pH}$ is one of the most important parameters controlling uptake of heavy metals from aqueous solutions. In all experiments, the initial $\mathrm{pH}$ of copper and zinc containing solution was adjusted to the desired value using $0.001 \mathrm{M} \mathrm{H}_{2} \mathrm{SO}_{4}$. Peat was added to the copper and zinc solution with adjusted $\mathrm{pH}$ and without maintaining the mixture at constant $\mathrm{pH}$ by sulphuric acid was noted that at the end of $24 \mathrm{~h}$ experiment the $\mathrm{pH}$ of all the solutions was decreased, see Figs 1 and 2. 


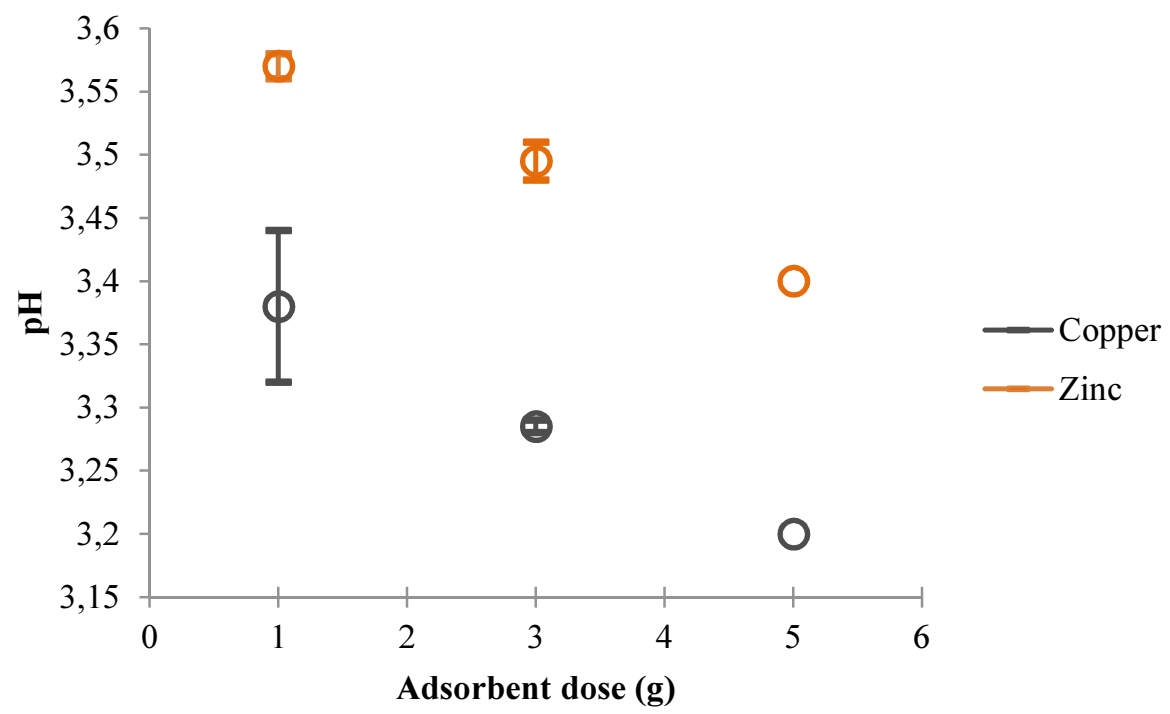

Fig. 1. $\mathrm{pH}$ values at the end of $24 \mathrm{~h}$ experiment at different adsorbent dose; single-component solutions, initial concentration $50 \mathrm{mg} / \mathrm{L}$

This $\mathrm{pH}$ decreasing is due the mechanism of sorption process. According to data from literature ion-exchange is the most prevalent mechanism for heavy metal removal by peat. The humification of peat produces humic and fulvic acids. Metals react with the carboxylic and phenolic acid groups of the acids to release protons or, at sufficiently high $\mathrm{pH}$, with their anion sites to displace an existing metal [12]. Studying nickel sorption Ho et al. observed that as the initial concentration of Ni increased, the equilibrium value of $\mathrm{pH}$ decreased [13]. This is accordance with the ion-exchange principles because as more nickel ions are adsorbed onto the peat, more hydrogen ions are released, thereby decreasing the $\mathrm{pH}$.

Probably this phenomenon was observed also at the adsorption experiments of copper and zinc, as resulting from comparison between results in Figs 1 and 2, where stronger decreasing of equilibrium value of $\mathrm{pH}$ was caused by increasing of the initial concentration of metals. Therefore cations of copper and zinc can form complex compounds with surface functional groups of peat, such as aromatic carboxylates $-\mathrm{COOH}$, and phenolic - $\mathrm{OH}$ through ion-exchange reactions, which lead to $\mathrm{pH}$ decreasing.

Another phenomenon that supports this theory is the adsorbent dose, whereas with increasing adsorbent dose decreases $\mathrm{pH}$ value.

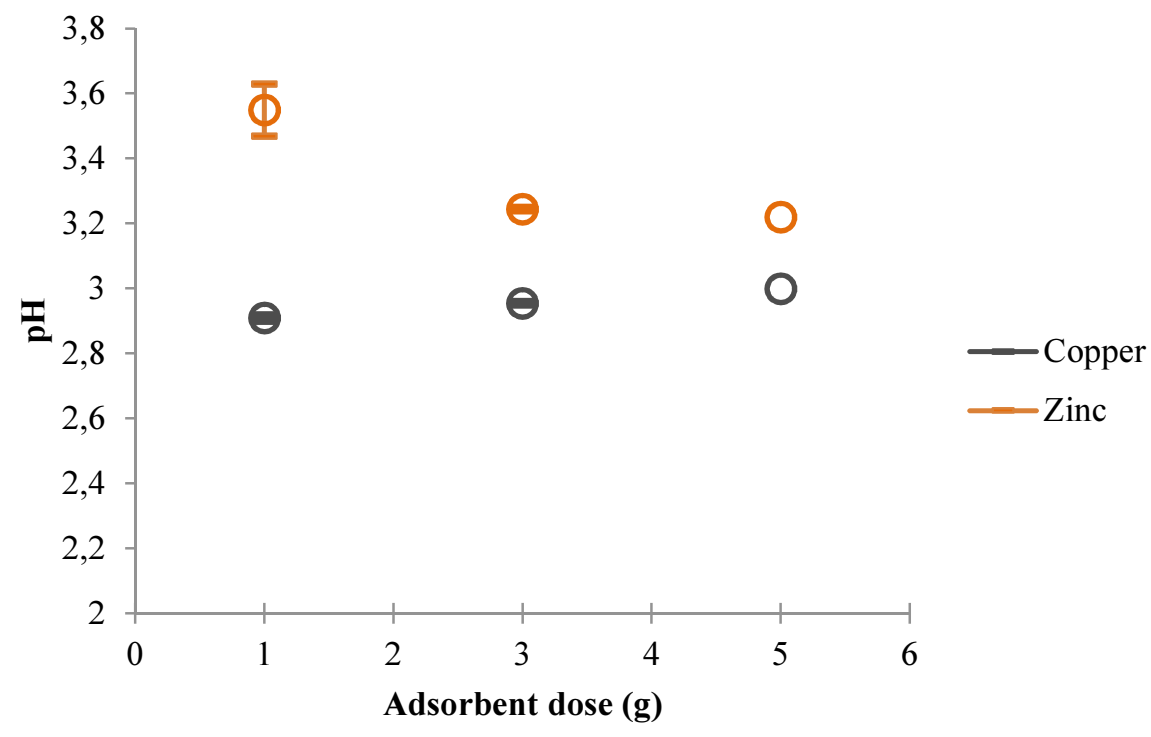

Fig. 2. $\mathrm{pH}$ values at the end of $24 \mathrm{~h}$ experiment at different adsorbent dose; single-component solutions, initial concentration $110 \mathrm{mg} / \mathrm{L}$ 


\subsection{Dual-component solutions efficiencies}

However, in practice, AMD contains a mixture of different heavy metal ions and sulphates. Due to this fact experiments were also carried out with two sorts of cations in solutions, to investigate their influence on sorption. The results of the heavy metals adsorption from both single- and dual-component solutions are compared in Figs 3 and 4.

The differences between adsorption of single- and dual-component solutions with initial concentration of $50 \mathrm{mg} / \mathrm{L}$ are not significant. However, at solutions with initial concentration of $110 \mathrm{mg} / \mathrm{L}$ differences up to $18 \%$ were reached.

In all experiments the sorption efficiencies per unit mass of peat was higher for single-component solutions compared to dual-component solutions.

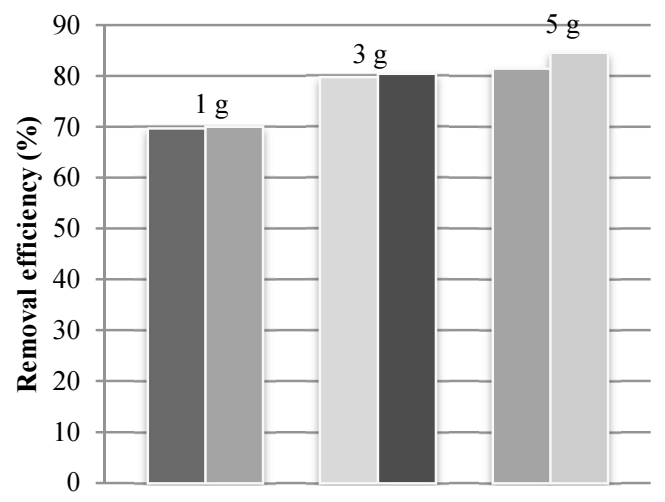

(a)

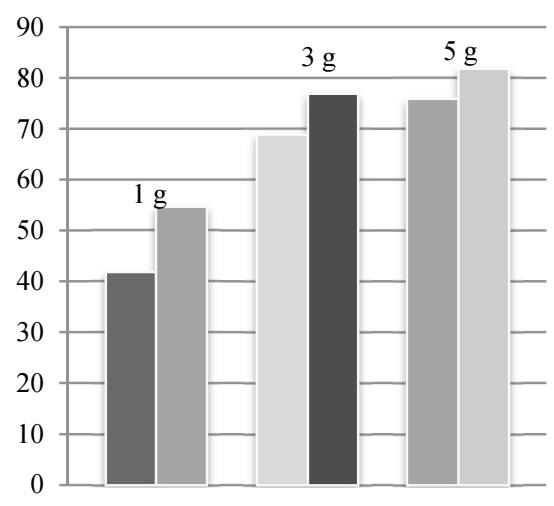

- $\mathrm{Cu}$ (Dual-solution)

- $\mathrm{Cu}$ (Single component)

$\mathrm{Cu}$ (Dual-solution)

- $\mathrm{Cu}$ (Single component)

- $\mathrm{Cu}$ (Dual-solution)

$\mathrm{Cu}$ (Single-solution)

Fig. 3. Comparison of the removal efficiencies of copper from single- and dual-component solutions / batching: $1.0 \mathrm{~g}, 3.0 \mathrm{~g}$ and $5.0 \mathrm{~g}$ peat/100 mL solution; $\mathrm{pH} 4.0$; Initial concentration (a) $50 \mathrm{mg} / \mathrm{L}$, (b) $110 \mathrm{mg} / \mathrm{L} /$

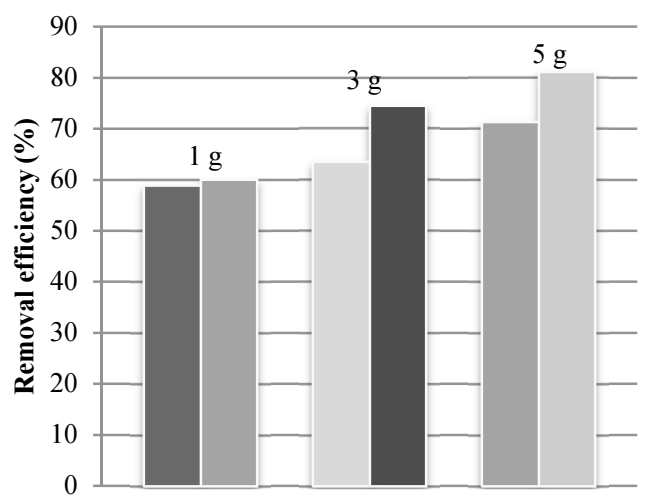

(a)

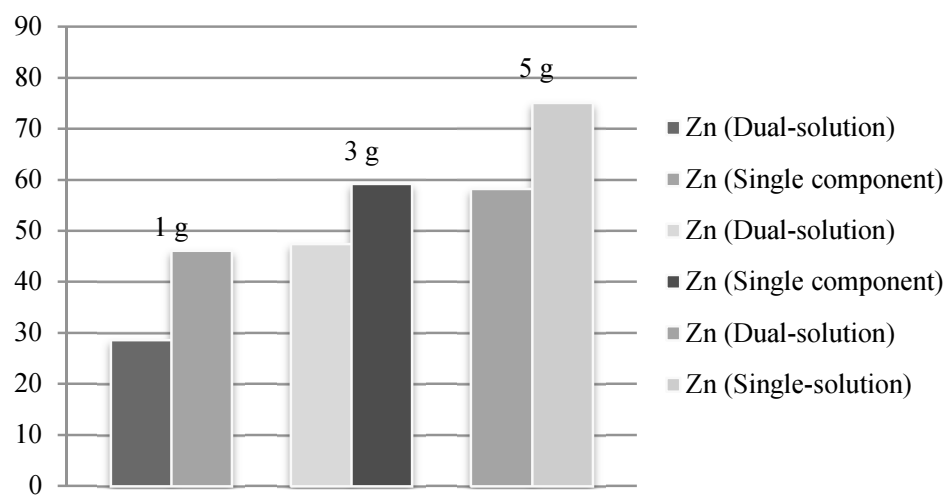

(b)

Fig. 4. Comparison of the removal efficiencies of zinc from single- and dual-component solutions / batching: $1.0 \mathrm{~g}, 3.0 \mathrm{~g}$ and $5.0 \mathrm{~g}$ peat/100 mL solution; $\mathrm{pH} 4.0$; Initial concentration (a) $50 \mathrm{mg} / \mathrm{L}$, (b) $110 \mathrm{mg} / \mathrm{L} /$

\section{Conclusions}

The aim of this paper was investigate adsorption properties of peat for the purpose of copper and zinc removal from AMD.

In the first stage the experiments were focused on the study of adsorption efficiencies in single-component solutions. The metals removal from synthetic model solutions was about $85 \%$ and $81 \%$ of $\mathrm{Cu}^{2+}$ and $\mathrm{Zn}^{2+}$ respectively.

In dual-component solutions the sorption efficiencies are affected by mutual competition of adsorbed cations. The efficiencies of metals removal in dual-component solutions were decreased up to $20 \%$ and $14 \%$ for $\mathrm{Zn}$ (II) and $\mathrm{Cu}$ (II) respectively compared to their single component solutions. From the result is evident that copper cations are adsorbed better than zinc, which corresponds to all obtained results in this study. 


\section{Acknowledgements}

This work has been supported by the Slovak Research and Development Agency under the contract No. APVV-0252-10 and by the Slovak Grant Agency for Science (Grant No. 1/0882/11).

\section{References}

[1] Gündogan, R.; Acemioglu, B.; Hakki Alma, M. 2004. Copper (II) adsorption from aqueous solution by herbaceous peat, Journal of Colloid and Interface Science 269: 303-309. http://dx.doi.org/10.1016/S0021-9797(03)00762-8

[2] Sabiha-Javied, T.; Mehmood, M. M.; Chaudhry, M; Tufail, N. I. 2009. Heavy metal pollution from phosphate rock used for the production of fertilizer in Pakistan, Microchemical Journal 91(1): 94-99. http://dx.doi.org/10.1016/j.microc.2008.08.009

[3] Ríos, C. A.; Williams, C. D.; Roberts, C. L. 2008. Removal of heavy metals from acid mine drainage (AMD) using coal fly ash, natural clinker and synthetic zeolites, Journal of Hazardous Materials 156(1-3): 23-35. http://dx.doi.org/10.1016/j.jhazmat.2007.11.123

[4] Dabrowski, A.; Hubicki, Z.; Podkościelny, P.; Robens, E. 2004. Selective removal of the heavy metal ions from waters and industrial wastewaters by ion-exchange method, Chemosphere 56(2): 91-106. http://dx.doi.org/10.1016/j.chemosphere.2004.03.006

[5] Peng, Y-Z.; Huang, Y-M.; Yuan, D-X.; Li, Y.; Gong, Z-B. 2012. Rapid Analysis of Heavy Metals in Coastal Seawater Using Preconcentration with Precipitation/Co-precipitation on Membrane and Detection with X-Ray Fluorescence, Chinese Journal of Analytical Chemistry 40(6): 877-882. http://dx.doi.org/10.1016/S1872-2040(11)60554-9

[6] Huang, Y-Ch.; Koseoglu, S. S. 1993. Separation of heavy metals from industrial waste streams by membrane separation technology, Waste Management 13(5-7): 481-501. http://dx.doi.org/10.1016/0956-053X(93)90079-C

[7] Brown, P. A.; Gill, S. A.; Allen, S. J. 2000. Metal removal from wastewater using peat, Wat. Res.34(16): 3907-3916. http://dx.doi.org/10.1016/S00431354(00)00152-4

[8] Sposito, G. 1989. Soil organic matter. The chemistry of soils. New York: Oxford University Press, 51-55.

[9] Cooper, D. G.; Eccles, E. R. A.; Sheppard, J. D. 1988. The effect of charged additives and heat pretreatment on the dewatering of fuel-grade peat, Can. Jour. Chem. Eng. 66: 945-949. http://dx.doi.org/10.1002/cjce.5450660608

[10] Forsberg, S.; Aldén, L. 1988. Dewatering of peat: characterization of colloidal and subcolloidal particles in peat, Colloids. Surf 34: 335-343 http://dx.doi.org/10.1016/0166-6622(88)80158-6

[11] Ringqvist, L.; Oborn, I. 2002. Copper and zinc adsorption onto poorly humidified Sphagnum and Carex peat, Water Research 36: 2233-2242. http://dx.doi.org/10.1016/S0043-1354(01)00431-6

[12] Gossett, T.; Trancart, J.-L.; Thevenot, D. R. 1986. Batch metal removal by peat kinetics and thermodynamics, Water Research 20(1):21-26. http://dx.doi.org/10.1016/0043-1354(86)90209-5

[13] Ho, Y. S.; Wase, D. A. J.; Forster, C. F. 1995. Batch nickel removal from aqueous solution by Sphagnum moss peat, Water Research 29(5): 13271332. http://dx.doi.org/10.1016/0043-1354(94)00236-Z 